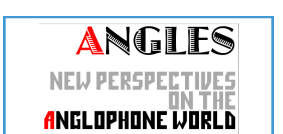

ANELOPHONE WORLD

\section{Angles}

New Perspectives on the Anglophone World

$11 \mid 2020$

Are You Game?

\title{
“There's a sniper on that hill!": Gaming in English as a Global Language Environment
}

Jeni Peake and Alexandra Reynolds

\section{(2) OpenEdition}

1 Journals

\section{Electronic version}

URL: https://journals.openedition.org/angles/3237

DOI: 10.4000/angles.3237

ISSN: 2274-2042

\section{Publisher}

Société des Anglicistes de l'Enseignement Supérieur

\section{Electronic reference}

Jeni Peake and Alexandra Reynolds, "'There's a sniper on that hill!": Gaming in English as a Global Language Environment", Angles [Online], 11 | 2020, Online since 01 November 2020, connection on 06 June 2022. URL: http://journals.openedition.org/angles/3237 ; DOI: https://doi.org/10.4000/angles. 3237

This text was automatically generated on 6 June 2022 .

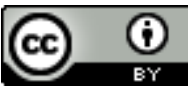

Angles est mise à disposition selon les termes de la Licence Creative Commons Attribution 4.0 International. 


\section{“There's a sniper on that hill!": Gaming in English as a Global Language Environment}

Jeni Peake and Alexandra Reynolds

\section{Introduction}

1 For many speakers of English as a Second Language (L2), the online gaming ${ }^{1}$ world provides unlimited access to the wider English-speaking community of speakers of English as a lingua franca (Jenkins 2015; Kachru 1992) through written forms, such as instant messaging, and oral forms with the use of connected headsets. Through online gaming, gamers can develop computer literacy skills which are increasingly recognised as key communication skills learners need to develop (Burwell 2017; Godwin-Jones 2004).

2 The ever-increasing popularity of digital games has inspired educators to consider the impact online gaming has on language learning (Wang et al. 2017). The present study considers online gaming which occurs outside of the classroom but which nevertheless impacts the holistic language learning identities of gamers who are also university students. Although some university programmes have included gamification as part of their university syllabi, the present study considers student attitudes to gaming for leisure in English. Those who argue in favour of gamification as an institutional tool say that language learning requires a context in which engaging games provide a more meaningful situation for learners to use the language than drilling and practice games (Chiu et al. 2012). ${ }^{2}$ We nevertheless consider online gaming as a learning environment because the gamers are immersed in a second language, in this case English, and they must understand the instructions and communicate with other players in English in order to play and advance in the game.

3 Given that online gaming is primarily a leisure activity, we can assume that the online gaming context is a pleasant one, especially as it has been freely chosen by the gamer. 
In this respect, online gaming is a playful environment which can positively affect learning performance (Tsai et al. 2012). Roger Caillois defines playful environments as "free, separate, uncertain, and unproductive, yet regulated and make-believe" (2001: ix); Callois's dictum notwithstanding, the present study would argue that gaming is productive in terms of English language development.

The present article focuses on the context of online gaming for English language learning through a leisure activity. We will first analyse the current literature and main concepts within the concept of online gaming for language learning. We discuss the different contexts for language use within online gaming, including speaking through headsets, instant messaging, forums, and reviewing gaming techniques through tutorials on YouTube.

We then present the methods used to interview young French students who play online games in English, as well as a collection of examples of gaming language used in written form. We then present the results of our questionnaire. The interviews with French youths show that non-educational online gaming has a positive effect on the confidence and language skills of the players. In addition, the corpus of gaming language found in open spaces at the University of Bordeaux highlights how the youths develop English language skills as part of their academic and personal identity.

6 The study reveals that non-educational online games are valuable tools that youths can choose to use in order to improve their English skills in an informal environment, which would complement other more formal language-learning contexts. ${ }^{3}$ These noneducational games can be used to educate in the same way as serious games ${ }^{4}$ which "aim to teach, inform, train or test uses users while they play" (Alvarez \& Michaud 2008: 9).

\section{Literature Review}

\section{Understanding Gaming: Objectives, rewards, and motivation}

7 Online video gaming ${ }^{5}$ can be defined as a leisure activity involving a computer or other technical support such as mobile phones or video consoles, with additional equipment such as a keyboard, console, and headphones. Games are part of all cultural identities in general, albeit Johan Huizinga argued that "play is older than culture" (Huizinga 1988: 1). Video games are no exception in triggering "powerful emotional responses, such as curiosity, frustration and joy" (Buckley \& Doyle 2016: 1162; McGonigal 2011). It is perhaps not surprising, therefore, that Henritius et al. found that user "satisfaction" was the most common emotion-related concept related to studies of virtual learning, of which gaming is an example (2019).

8 Like other games, video games have final objectives and specific rules. These rules need to be understood and progressively mastered to advance in the game. Video games are based on a rewards system for achieving certain levels, achieving goals or overcoming obstacles (Smith-Robbins 2011; Glover 2013; Buckley \& Doyle 2016). These rewards can take the virtual form of tokens, ranks, prizes, badges, or trophies. Zicherman and Cunningham (2011) refer to these types of rewards as SAPS (Status, Access, Power and Stuff). Buckley and Doyle acutely point out that rewards for learning are paradigmatic to current educational systems where grade and qualification "trophies" are key to their rewards system (Buckley \& Doyle 2016: 3). Likewise, the competitive element of 
gaming results in a leader board ranking top achieving players. These rankings are “publicly and instantly recognized" (Buckley \& Doyle 2016: 3; Domínguez et al. 2013). One recent example of public ranking of this kind was 16-year-old Kyle Giersdorf who won $\$ 3$ million as the highest scoring Fortnite player (Taylor \& Chokshi 2019).

A feature specific to gaming, as opposed to more formal educational contexts, is perhaps the greater acceptance of failure as part of the gaming or educational journey:

A key objective of most games is not to forbid failure but to develop a positive relationship with it. Failure is not seen as an end, but as a step on the journey to mastery. (Buckley \& Doyle 2016: 3)

Gaming is thus understood as a problem-solving, rule-driven, competitive, and rewardbased activity. It is for this reason that gaming can be categorized as a virtual learning activity firmly associated to the world of education. Virtual learning is considered as "non-physical learning that utilizes technology including online and offline solutions" (Henritius et al. 2019: 80). The definition of virtual learning is closely aligned to the definition of gaming as being representative of learning via technology. However, gamers initiate the activity in online gaming, whereas educators initiate virtual learning in formal institutional contexts. This is a first step in understanding motivation for gaming but also in understanding those who are behind the scenes of virtual technology. In gaming, product designers and marketers have specific sales objectives and motives (Zichermann \& Cunningham 2011; Buckley \& Doyle 2016). Educators also wish to align their students' activities with their institutional rewards system, whilst working within the constraints of institutional demands.

The motivational drive for gaming is strongly tied to motivational theories ${ }^{6}$ in relation to why learners wish to learn. The two main types of categories of student motivation are usually referred to as intrinsic and extrinsic motivations (Deci et al. 2001) although these categories are broad strokes of much finer and contextualized categories. ${ }^{7}$ If intrinsic motivation involves learners being interested in the tasks themselves, then this could apply to gamers who enjoy gaming as an activity: "Some learn for pleasure or to satisfy curiosity, whereas others learn to obtain rewards" (Buckley \& Doyle 2016: 5).

If extrinsic motivation involves learners wishing to learn as a means to an end (for example, winning the game, or achieving a grade), then gaming also involves extrinsic motivation.

\section{Insights into Gaming Interaction}

Current virtual learning theories argue that successful language learning occurs "in the wild" (Thorne 2010: 144) and that the online interaction provided by gaming gives L2 speakers access to real talk rather than the techniques used in the second language classroom such as simulations or role-playing activities (Kohn \& Hoffstaedter 2017; Thorne 2010). Communication during online game play takes many forms. Firstly, in the form of synchronous activities such as instant messaging, written texts, and talking via headsets. Secondly, in the form of asynchronous activities such as forums and online reviews. Asynchronous texts in gaming are referred to as "paratexts" (Burwell 2017). Asynchronous online learning is defined as learning that occurs without a realtime component (Majeski et al. 2016: 111). Learners can use paratexts surrounding the game frames in their own time and at their own pace. L2 speakers of English use these texts in the same way as they would read for the purposes of learning English, for 
example by looking up words they did not know. Asynchronous learning involving paratexts, which particularly focuses on reading and writing skills, is autonomous and self-directed (Sanborn 2016).

Gamers are sometimes required to communicate through computer-controlled characters by selecting an option in order to advance in the game. This method of communicating through gaming is an example of controlled language practice whereby gamers choose between different options. This is the case in some online games where the players can only communicate through predefined answers. This can be seen in Figures 1 and 2 where the pre-defined choices are thank, emote, hello, need healing, group up, ultimate status, voice line and acknowledge. The game interface, in this case, limits communication between the players.

Figure 1: Predefined phrases in Overwatch

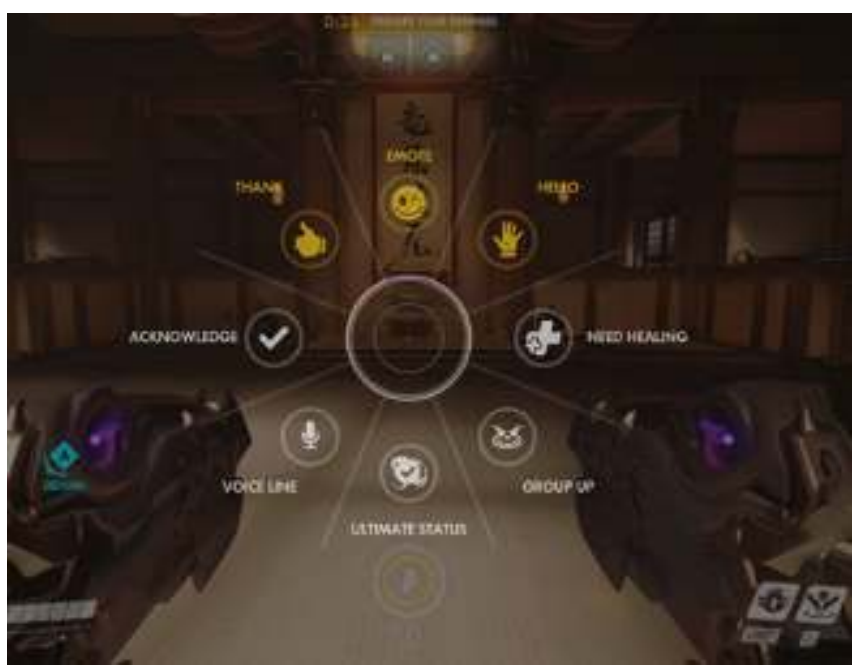

Player's name has been obscured for anonymity.

Credits: Overwatch. Blizzard Entertainment. 
Figure 2: Predefined phrases in Clash Royale

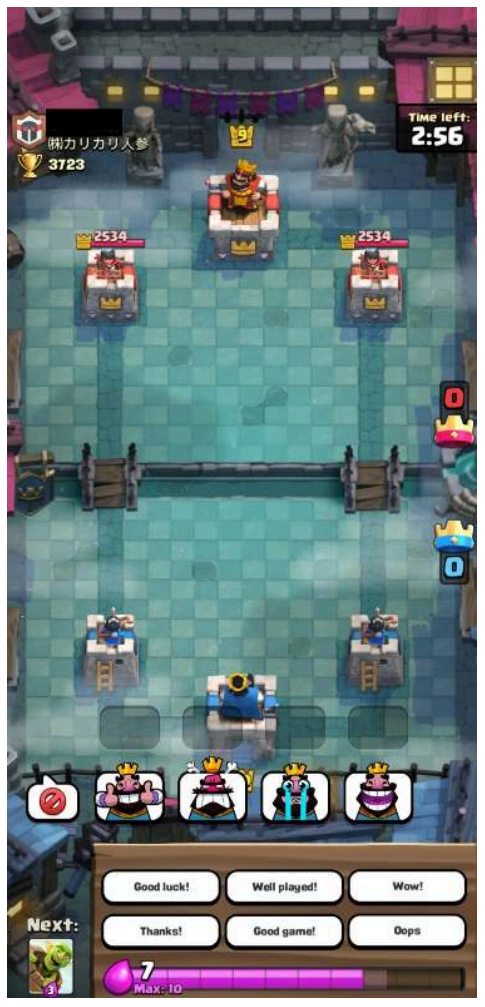

Player's name has been obscured for anonymity.

Credits: Clash Royale. Supercell.

15 Gamers can also engage in free creative writing when they write open messages to communicate with the other human controlled players. In Figure 3, we can see that the players are able to write freely to communicate with each other. The chat box allows players to communicate with other players without any pre-defined language restrictions. The players then choose to communicate in long or short sentences, using general or game-specific acronyms. 
Figure 3: League of Legends and Overwatch chat boxes

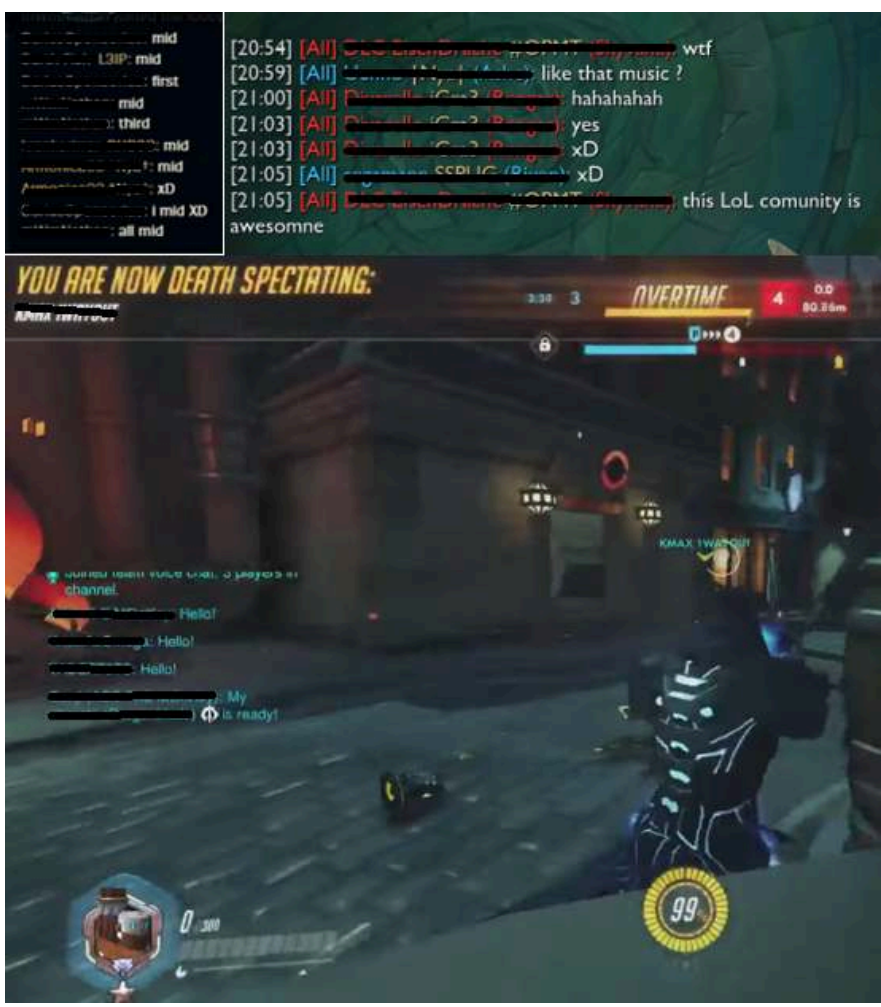

Players' names have been obscured for anonymity.

Credits: League of Legends. Riot Games. Overwatch. Blizzard Entertainment.

Multi-modality is a feature of the online game environment and is related to working memory (Wei et al. 2018). Multitasking ability in a multi-modal game involves several executive cognitive functions, including inhibition, interference control, and working memory (Chang et al. 2017: 654; Miyake \& Friedman 2000). Learning with online gaming can be attributed to the functions of Information Processing Theory (IPT), which is based on the review process induced from short-term to long-term acquisition (Wei et al. 2018). One variant of IPT is Cognitive Information Processing (CIP), which is made up of three different components: knowledge, decision-making skills, and executive processing domain, i.e. thinking about thinking (Reardon \& Wright 1999). Research has shown the importance of information processing theory in relation to multi-modal learning contexts, as well as being increasingly supported by cognitive neuroscience research (Wentzel \& Miele 2016; Tangen \& Borders 2017). Yip and Kwan (2006) have shown that online games helped to achieve both learning and longer memory retention in participants. In addition, online games that feature several gamers can be considered as complex forms of interactive media that challenge social and cognitive skills (Thorne et al. 2009).

17 Learning through games can increase motivation, reduce anxiety and promote educational outcomes (Young \& Wang 2014). Indeed, anxiety when learning a foreign language can be attributed to the feeling of inability to use the second language and the skills that accompany it (Wei et al. 2018). Additionally, Elkhafaifi (2005) has shown that students who suffer from second language anxiety tend to underestimate their ability and eventually have lower scores and performances. Although gamers may be anxious 
about losing a game, the English language they use is a means to an end, rather than the primary objective of play.

Gaming, where users put into application their already existing language repertoires in an informal context, involves verbal expression. In the case of online gaming, the game is the main goal and English language learning a secondary outcome of the gaming experience. This explains why some gamers are not deterred by playing an online game in English. The motivation to game overcomes the language barrier - if English can still be considered a as barrier for French university students who use English in a variety of both academic and non-academic contexts (Reynolds 2016). With practice, the second language (English) becomes an inherent feature of gaming as a global leisure activity through which English is used as a lingua franca.

Some learners of English may decide to immerse themselves in an English-speaking environment to improve their English language skills and gain access to a community of practice (Wenger 1999). It is through communities of practice that language learning takes place (Wenger 1999). This is because context and social interaction are key when learning a language (Lantolf \& Thorne 2006). In particular, gaming helps players develop their communication skills without having to travel physically (Ducheneaut \& Moore 2004). Gaming is one way of breaking down the geographical barriers between speakers of English. The nature of online activity creates a sense of community amongst the different members (Jiangnan et al. 2014); this is particularly relevant in online gaming communities (Hsiao \& Chiou 2017).

\section{Research question}

The aim of this paper is to examine student attitudes to language learning in relation to online video gaming in English as a leisure activity. Examples of oral and written English used by players when gaming were collected into a small corpus to better assess the attributes of English within the context of online gaming.

\section{Methods}

The present study is based on the testimonies of 90 French speakers of English who use online games in English. ${ }^{8}$ The participants were students from the School of Science ${ }^{9}$ of the University of Bordeaux, France, who played online games outside of university hours as a leisure activity. The participants were 21 years old on average; $85 \%$ were male. ${ }^{10}$ All of the participants indicated that they spoke at least two languages, English being the first of their second languages. ${ }^{11}$ The qualitative methods used were a questionnaire and semi-directive interviews and photographs taken of gaming language written as desktop graffiti.

The participants were asked which online games they played in English and how they communicated with other players in English. The participants were also asked if they could recall specific vocabulary related to gaming. The participants were asked if gaming had helped them develop their English language skills. The full interview schedule is included in the appendix. Pseudonyms were attributed to the participants. 


\section{Results}

eague of Legends (57 citations), Counter Strike (38 citations), Minecraft (33 citations), Overwatch (18 citations), Call of Duty (14 citations), World of Warcraft (13 citations). League of Legends is a role-playing game involving real time strategy. Counter Strike, Global Offensive Overwatch and Call of Duty are multiplayer First-Person shooter games. World of Warcraft is a massive multiplayer online role-playing game (MMORPG) and Minecraft is a multiplayer online Indie Sandbox game. The results show that the most cited game types were multiplayer First-Person shooter and role-playing games. On average, the participants played 2.7 games where the game's language settings were in English and 1.6 games where English oral (speaking and listening) communication was necessary to progress in the game.

The nature of the online game influences the degree to which the players interact with each other in English. Online multiplayer gaming, for example, involves complex English communication skills, including cooperation and negotiation with other players. The nature of massively multiplayer online games (MMOGs) lends itself to interaction between players where they must communicate and work together in order to solve problems and complete tasks to advance in the game (Voulgari et al. 2014). MMOGs are therefore accessible learning environments for many because they are:

Extensions of life in a quite strict sense, since they recruit and externalise some of the most fundamental features of how beings orient themselves in and to the real world, especially when they are operating at their best. (Gee 2005: 95)

When the players are working together to advance in the game by finding objects, defeating enemies, solving puzzles, etc., they encounter a wide variety of vocabulary. 
This can be, for example, objects and places within the game or the verbs used to control the movement of the online characters. As shown in Figure 4, the game provides the players with directional (steer and drift), positioning (tilt), and movement (accelerate) vocabulary that can be applied to other areas of English.

Figure 4: Screenshot of Mario Kart 8: Game Play in English

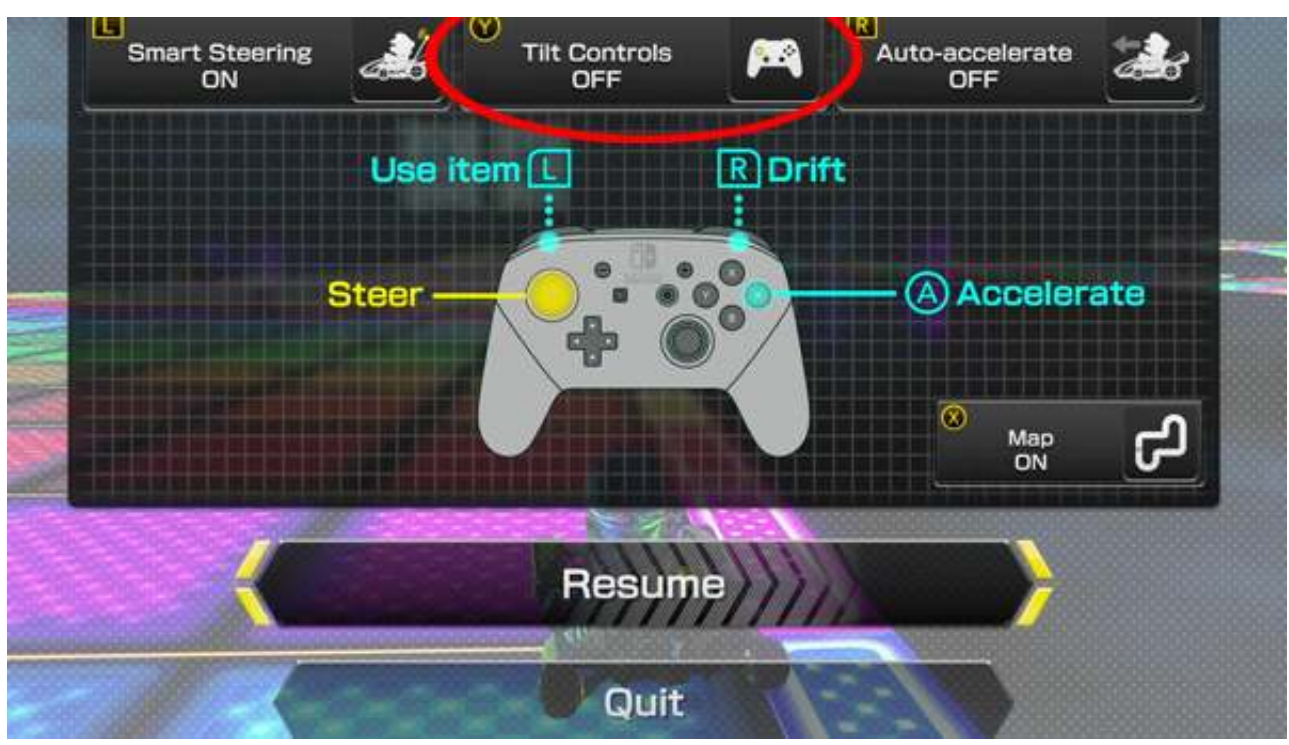

Credits: Mario Kart. Nintendo.

Whether the participants associated the acquisition of vocabulary with the gaming context was addressed by asking them if they associated specific words to the world of gaming. The participants were asked if they could identify any particular words they had learnt when video gaming. Although the working hypothesis was that participants might not be able to identify a particular given context through which specific vocabulary had been acquired, the participants nevertheless disproved this hypothesis by citing 328 words that they had learnt through gaming. 71 participants provided a word list of an average of 4.6 words that they related to gaming specifically. These words were principally nouns (209) such as "a shovel, a pickaxe, a chainmail and forklift". Full phrases were also cited, including: "make your acquaintance", "I'm heading west" and "There's a sniper on that hill!" The vocabulary cited by the respondents according to semantic fields is summarised in Table 1 . The full list of words cited by the respondents is reproduced in the Appendix.

Table 1: Table of vocabulary per grammatical form cited by the participants

\begin{tabular}{|l|l|l|l|l|l|}
\hline $\begin{array}{l}\text { Part } \\
\text { Speech }\end{array}$ & Nouns & Verbs & Interjections & Adjectives & Adverbs \\
\hline Frequency & 209 & 78 & 24 & 13 & 4 \\
\hline Percentage & $64 \%$ & $24 \%$ & $7 \%$ & $4 \%$ & $1 \%$ \\
\hline
\end{tabular}




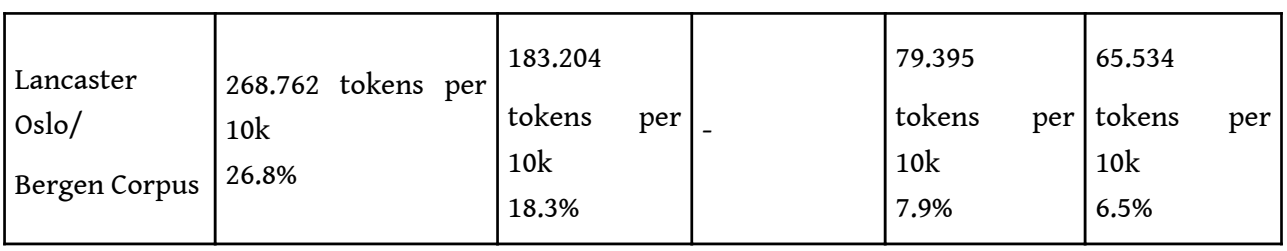

$65 \%$ of the words cited by the participants were nouns; verbs accounted for $24 \%$ of the words learnt through gaming. When comparing these results to the LOB (Lancaster Oslo Bergen) corpus, our "gaming" corpus contained a higher percentage of nouns. This can be explained by online gaming involving places and objects within the game scenery. These noun objects are also the prizes which the players need to collect as they progress through the game. The results show that the nouns fell into five main lexical fields (Table 2) related to the places and objects which the participants used in the games.

Table 2: Gaming word categories per lexical field

\begin{tabular}{|l|l|l|l|l|l|}
\hline Lexical Theme & Objects & Weaponry & Minerals & Places & Tools \\
\hline Frequency & 63 & 23 & 13 & 9 & 4 \\
\hline Percentage & $22 \%$ & $8 \%$ & $4 \%$ & $3 \%$ & $1 \%$ \\
\hline
\end{tabular}

31 The nouns were categorised according to lexical themes, revealing a trend in mining and wartime vocabulary. The gaming nouns cited by the participants showed examples of concrete nouns (such as gate shovel, ore, chainmail, library), and abstract nouns (health, tournament, and heist). Not surprisingly, the lexical fields were linked to the general game themes: Minecraft teaches geological and landscape vocabulary such as iron and coal because it is a game based on mining materials and creating buildings; Call of Duty teaches modern warfare terms including barracks and assault rifle.

The results show that gaming in English allows students to learn unusual and quirky words that they may not necessarily come across in formal language learning contexts. However, this does not mean that these expressions are useless. Language is a repertoire that can be used and cross-referenced in multiple contexts according to need. Such quirky words include insults and inappropriate phrases, such as retarded, dummy, you suck and noob. Insults and rude words are not words participants use in their formal English language classroom. Gaming gives learners the opportunity to hear and use these phrases in an appropriate context and also gives them access to vernacular English.

\section{Gaming as a Global Community of English Speakers}

Overall, the participants could give specific examples of where their co-gamers were geographically located. Figure 5 shows the detail of the countries mentioned in the participants' open responses. The most often cited examples referred to countries belonging to the European Union. The result relating to identifying co-gamer location shows that the players were acutely aware of where their co-gamers were located and could give specific information regarding their geographic location. It must be noted 
however, that location does not equate with nationality. The participants gained location information via the gaming software, which sometimes geographically positions players on a map. The participants also gained this information by chatting with their co-gamers. It is noteworthy that the gamers know where they are in relation to each other: having access to geographical knowledge about other players reveals a specificity of gaming as an online but situated community of practice. The results also show that the players engaged in small talk (about their geographical locations) and that they were therefore not only "gaming". The games themselves serve not only as an area of play, but also as a communicative environment where gamers learn about each other.

The participants either decided to refer to their co-gamers as "Europeans", or identified the countries belonging to Europe. Great Britain, in keeping with Brexit, was identified as non-European by the participants. After Europe, Great Britain and the United States were high-ranking examples of locations more traditionally associated with English language use (see Figure 4 for full details). Nevertheless, English was undoubtedly the language of gaming in all of these locations. The present study therefore confirms the international aspect of gaming in English, where no continent is left unmentioned. The gamers were aware of the international aspect of gaming and referred to gaming as international. As in other areas, such as scientific and academic English (Reynolds 2016; Phillipson 1992; Kachru 1992; Kachru 1986), gamers agreed that, overall, the de facto language of gaming was also English. One French-speaking participant remarked that he used English even when "gaming" with other Frenchspeaking players and said: "I'm speaking English, even with French players." (Anonymous survey response)

Figure 5: Word frequency of countries mentioned by gamers in the open questionnaire responses

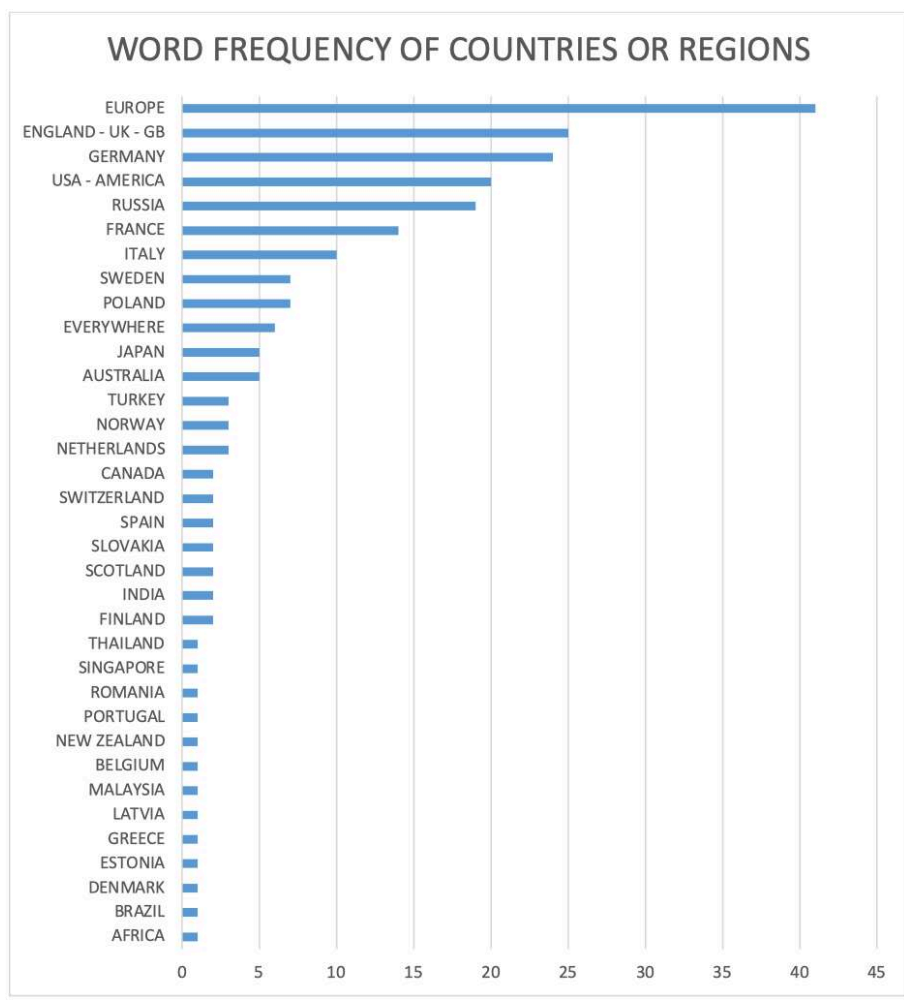

Credit: Peake and Reynolds 


\section{Interviews} (Pascal). he had played.

The students who were interviewed were asked whether they felt that gaming had helped them to improve their English and if so, how. In keeping with the questionnaire responses, the participants reported that gaming helped them with their English. One participant believed that his English language skills were almost entirely due to gaming: "90\% of my English learning came from speaking with people in games"

Another participant believed that online gaming in English had helped him to keep up with his English classes in lycée (high school) despite never having attended English lessons at middle school:

Je n'avais pas de cours d'anglais, jusqu'au lycée... J'ai réussi à suivre [des cours d'anglais] malgré que [sic] je n'ai jamais eu de cours d'anglais et je pense que c'est que du coup [sic] grâce aux jeux vidéo. (Thomas)

Translation: ${ }^{12}$ I never had any English classes, not until high school... I managed to follow [English classes] despite never having had English classes and I think that it was thanks to video games.

Robert, a C1 level speaker of English, ${ }^{13}$ also believed that his current level of English was entirely "due to playing in English realms on World of Warcraft." He explained that he had had enough of playing in French realms and therefore turned to English ones. In addition, Robert met a British player in the game and they became friends. He believed his spoken English improved as they talked regularly both within and outside of the game. Robert believed his general English skills improved overall because gaming gave him access to a community of practice. It must be noted, however, that the participants were not pre- or post-tested for language proficiency, and their testimonies were a general impression of their self-assessed proficiency levels.

Three of the interviewed students believed that the games only helped them learn specific vocabulary. Anthony said that playing Minecraft taught him words such as "grass", "hardened clay" and "rocks". Whereas five other students said that they even learnt basic words when gaming. For example, Thomas remembered travelling to an English-speaking country and being able to recall the word "chair" from the games that

One of the main ways the students improved their English was through the forums, vlogs, and tournaments associated with the games they played. Benjamin explained that gamers play with a wide range of other nationalities, and since English is the language of communication, this was the only way he could understand everyone. Benjamin therefore described that all his English skills improved through gaming. His oral skills (speaking and listening) in English improved through talking to a variety of English speakers, and his reading and writing skills improved through participation in forums, vlogs and chats. This result is in keeping with the reference to the global English community of players referred to in the questionnaire results: "When playing and chatting with ten people from different countries, that's when we really improve our English." (Benjamin)

Three of the students mentioned that either there was no French translation of the less mainstream games or that the quality of the French translations was poor. The French translations could even confuse gamers, especially when looking for help. For example, the character Barnes in Zelda, Twilight Princess is called Crahmé in the French version of 
the game. The nomenclature of character names is a rich aspect of gaming and contributes to the general knowledge of gaming. Barnes's name may be a pun on 'burns', a point echoed in the French version with his translated name as Crahmé, a pun on the French slang for burnt, or 'cramé'. Not knowing the English name of a character could penalize a player who was looking for help, whereas having access to the English name of a character would enable a player to find help about the character in an English forum, for example. The participants' English was good enough to read instructions in English and gain more meaning from the English texts than in the poorer French translations. The students explained that being able to use English was also an advantage when searching for help and advice in forums. The participants could gain more help in English and they had more difficulty in finding the information they needed in French. Given that most paratexts in gaming are in English, the gamer has a better chance of finding an answer to a question in English than in French.

The only disadvantage relating to gaming in English that Robert and Anthony mentioned was that there were no "native speakers of English" in their group chat and no one to correct their English. They believed that this meant that they would "continue to make the same mistakes". This result shows that some participants still favoured native-like role models of the English language.

Nevertheless, the results show that the online nature of the exchanges between the players made the speakers feel more confident when trying to communicate in English (both within the game and when interacting with others in English when not gaming):

[Gaming] can decrease the shyness... because we just make conversations in English in a written way and so when we are speaking to other people we can remember the sentences, the forms, we have used to talk with other people and these sentences are then memorized and we can just use them without being shy or making mistakes because if we have made it, we've already made it in the game and some people have corrected us. (Anthony)

\section{Gaming as a Bounded Leisure Activity}

Despite having said that gaming helped their English, the students were unanimous in not wishing to mix pleasure with work. The students were asked if they would be in favour of a gaming room at the University Language Centre, for example. They did not favour a gaming room for the following reasons: gaming was described by Robert as "an escape from reality", especially from the formal setting of the University of Bordeaux; Thomas did not see the appeal of a room with online games he already had at home, and Robert did not like the idea of being "forced" to play an online game at University. Online gaming was considered a home leisure activity. However, the participants welcomed other types of games being used in an educational context (as long as this did not involve consoles or online games). Brigitte and Benjamin were in favour for using interactive multiplayer quizzes such as Kahoot and Jackbox in the classroom. Interactive multiplayer quizzes were indeed used on the participants' mobile phones in the physical presence of their peers and their English teacher. The participants' attitudes to their formal English language learning were mixed and often critical:

To be honest, we all know that English teachers, at high school, they're really, really awful, most of them at least, and it wasn't really working for anyone even. I was just in a corner of the room not saying anything or participating because I just didn't care at all. It's a bit different, but I know that it's not thanks to them that I'm fluent in English. (Robert) 

graffiti at the University of Bordeaux. Desktop graffiti are defined as "student-authored graffiti on student desktops" (Ball 2019: 1). Peake's study reveals that gaming is part of students' bilingual identities at the University of Bordeaux. Examples of desktop graffiti written in English in the lecture halls of the University of Bordeaux confirmed that gaming is relevant to student identity. Table 3 (a-f) gives examples of gaming terms found written or etched on desks at the University of Bordeaux:

Table 3 a: Gaming reference found on desktops at the University of Bordeaux

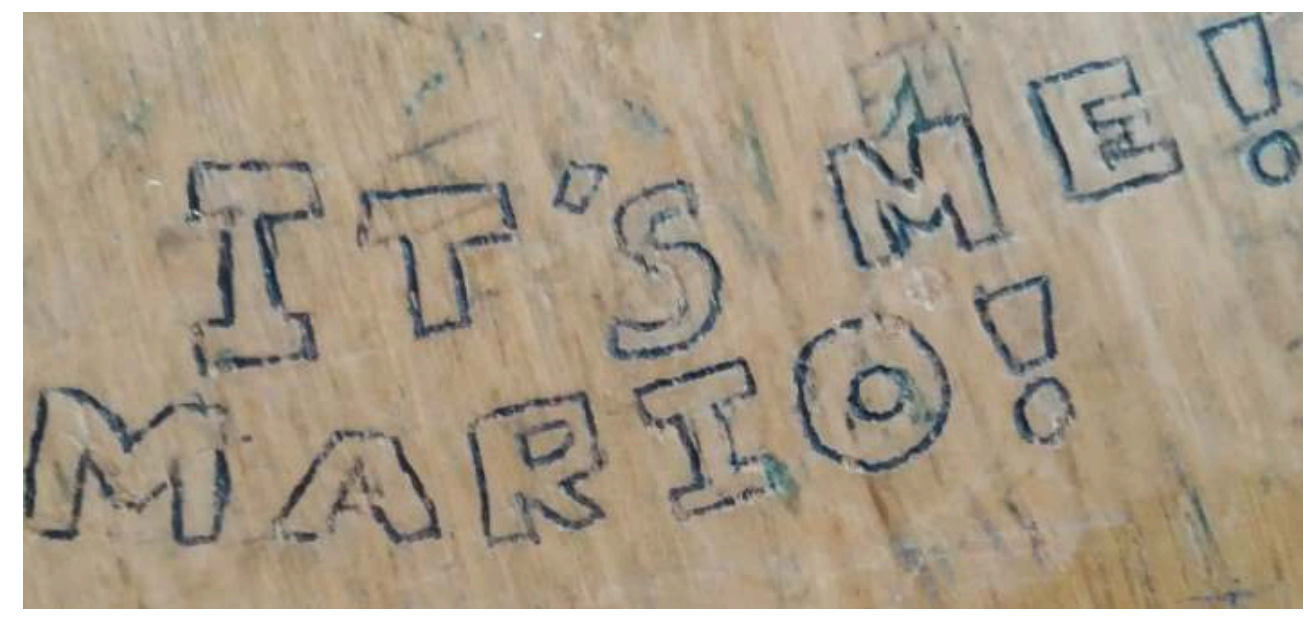

IT'S ME!

MARIO!

Photo: J. Peake. 
Table $3 \mathrm{~b}$ : Gaming reference found on desktops at the University of Bordeaux

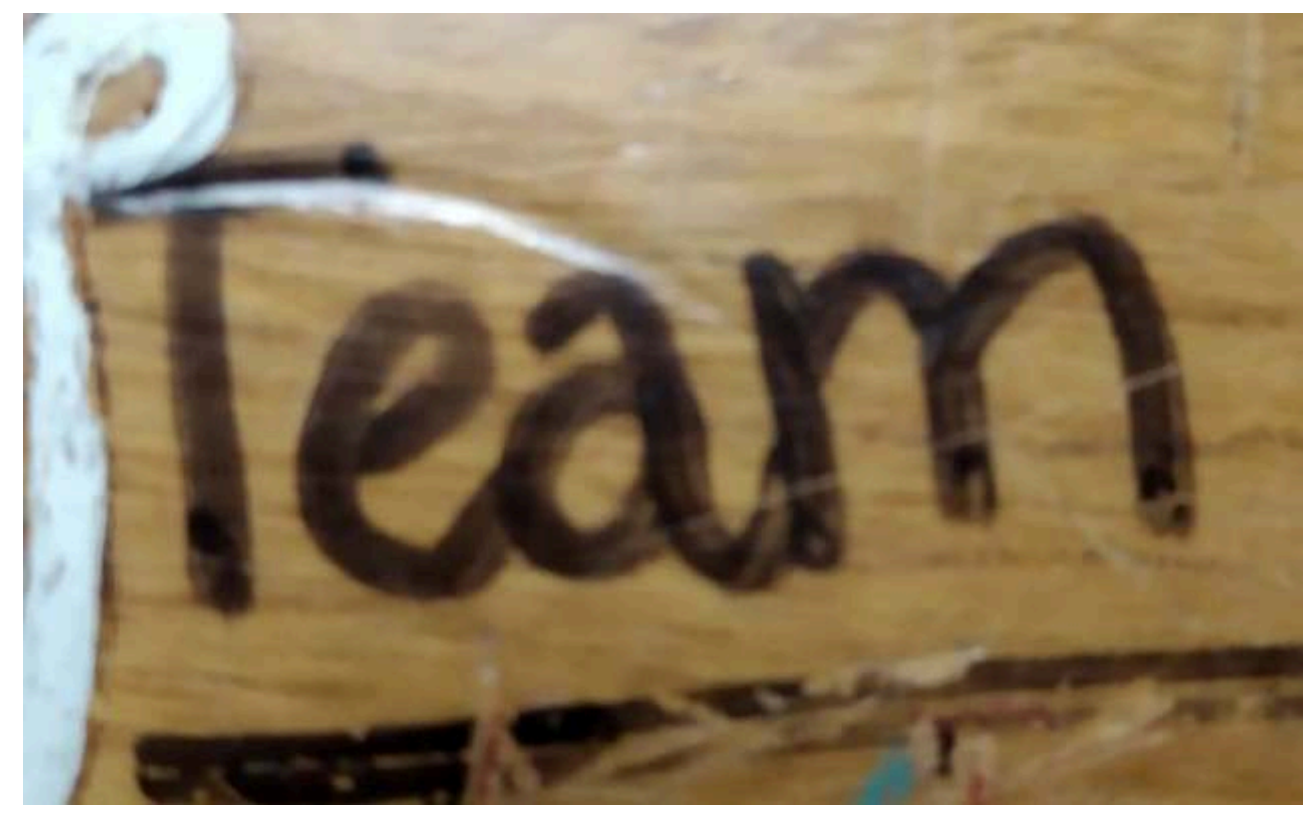

TEAM

Photo: J. Peake.

Table 3 c: Gaming reference found on desktops at the University of Bordeaux

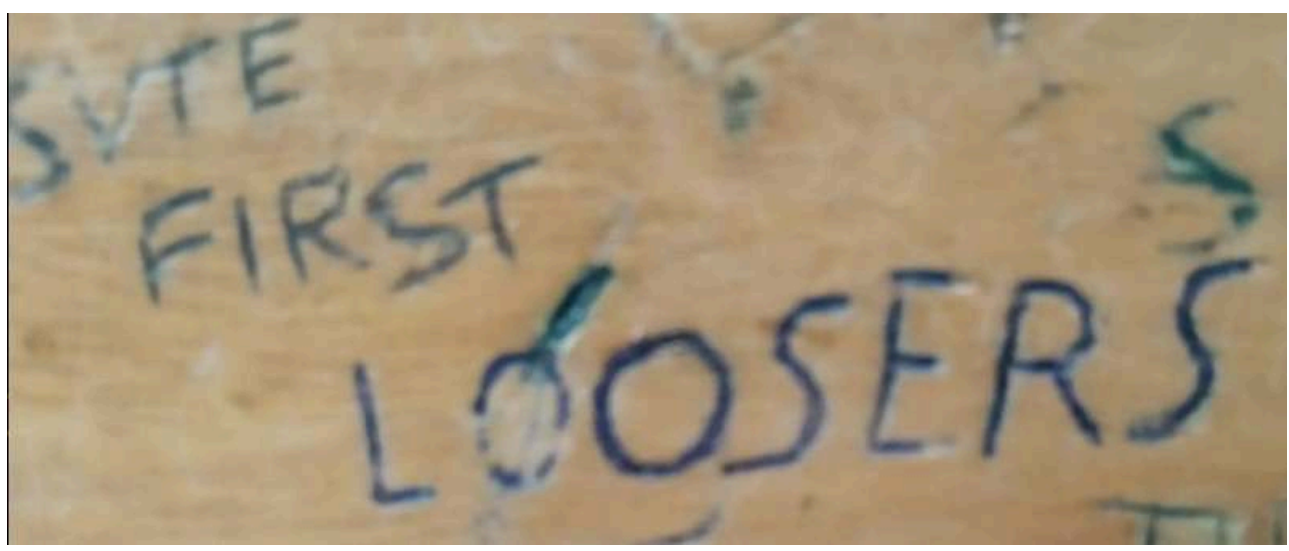

SVTE

FIRST

\section{LOOSERS}

Photo: J. Peake. 
Table $3 \mathrm{~d}$ : Gaming reference found on desktops at the University of Bordeaux

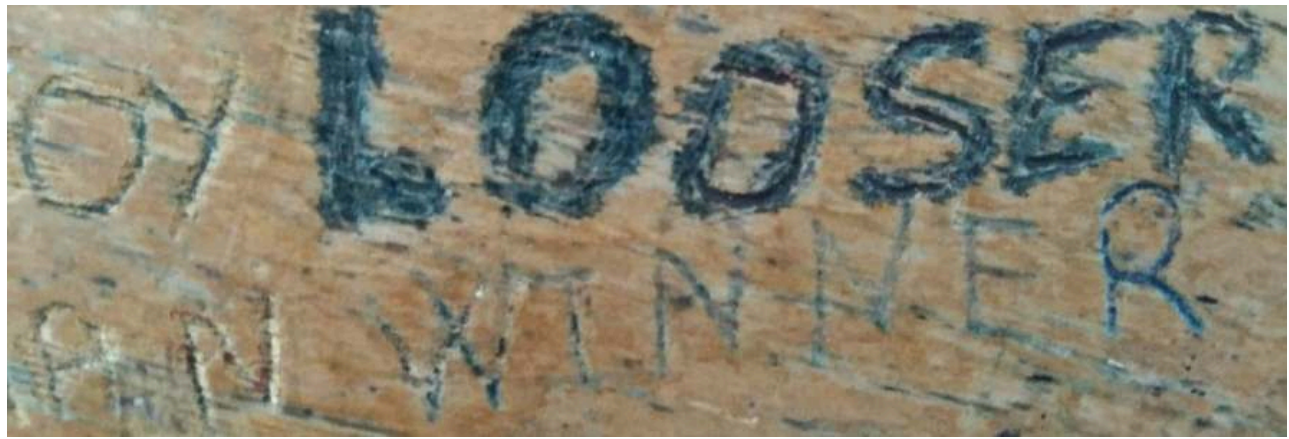

OY LOOSER

AN WINNER

Photo: J. Peake.

Table 3 e: Gaming reference found on desktops at the University of Bordeaux

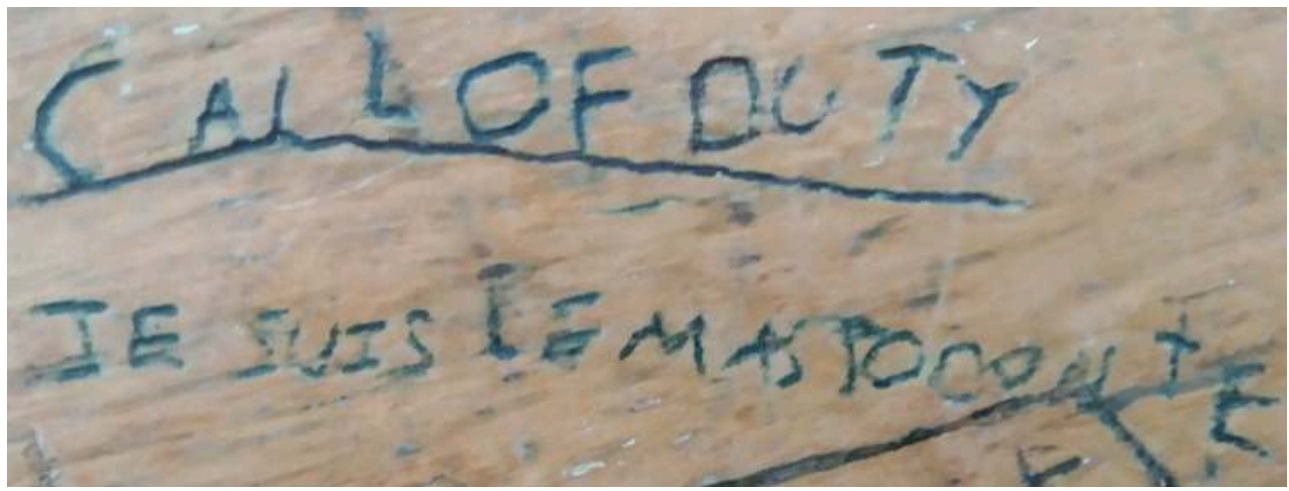

CALL OF DUTY

JE SUIS LE MASTODONTE

Photo: J. Peake.

Table $3 \mathrm{f}$ : Gaming reference found on desktops at the University of Bordeaux

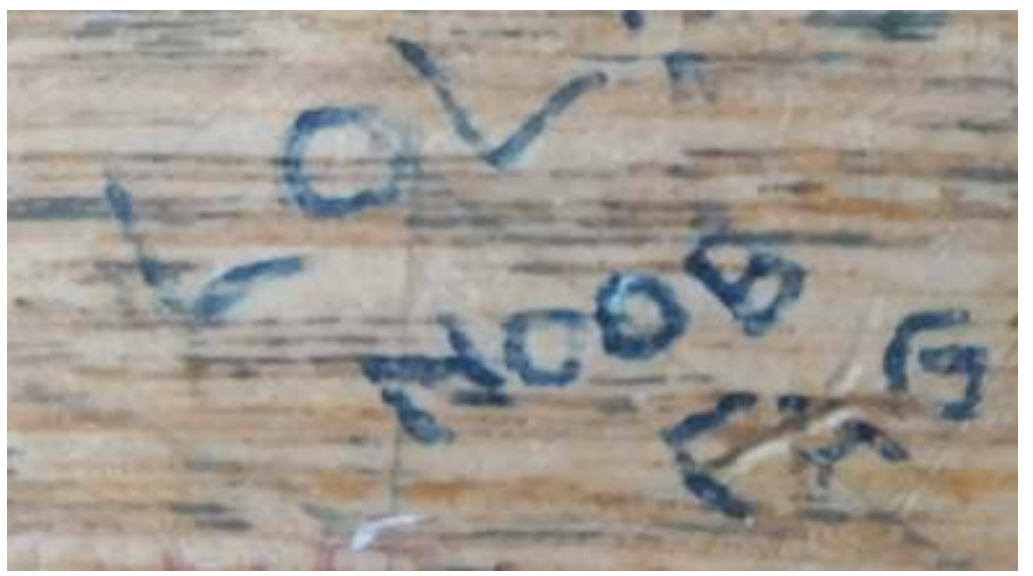

$\mathrm{LOL}$

NOOB

FAG

Photo: J. Peake. 
examples of desktop graffiti reveal that students decide to transfer texts from their virtual gaming environment to their local physical environments. The misspelt noun "loosers" refers to gaming terminology, but can also be a judgment on the abilities of either their lecturers or their peers. Catchphrases of popular games are referred to by the table-top writers, such as "It's me! Mario!" (3a) (a reference to the opening credits of Super Mario). There are also hybrid phrases such as: "Call of Duty, Je suis le mastodonte" (3e), with mastodonte referring to a heavily armoured character (a juggernaut) in the Call of Duty game series. "Noob" (3f) is a common insult used for gamers who are losing and implies that they are inexperienced players (Noob comes from the word new or newbie).

appearance of gaming graffiti at the University of Bordeaux can be interpreted as either acts of desktop vandalism or text art (Jaworski 2014) created by the students. In this case, students use their knowledge of both English and gaming to inscribe fictional stories on real (in this case, institutional) objects. That gaming should be used as the subject of these inscriptions reinforces the results that showed the practice (English) language of gaming is considered a counter-institutional act where "the meaning of graffiti is to protest, to defy" (Gross \& Gross 2016).

\section{Conclusion}

Gaming is a non-institutionalised activity in which English is one of the key tools. The study reveals that English, rather than French, is the language of online global gaming. English language skills gave the participants access to international communities of gamers where the use of French was a barrier to comprehension and communication. The immersive aspects of the online game gave the L2 speakers of English the ability to travel virtually outside of their L1 local language environment. In addition, the repetitive nature of online games and gaming vocabulary helped the participants to learn English words and phrases without the impression of being drilled.

As the present study consisted of French-speaking university students who also learnt English at university, careful attention was given to how the participants compared informal gaming in English to more formal English language learning activities. The results showed that student participants had no negative associations with gaming in English, whereas their attitudes to formal language learning were more mixed. The students appreciated being able to game in English as a leisure activity which was separate from formal education. Gaming as escapism from formal university education was also confirmed by the appearance of gaming graffiti at the University of Bordeaux as acts of desktop vandalism. These examples of gaming graffiti reinforce the noninstitutional and counter-institutional dimensions of gaming.

51 Motivation to play comes above and beyond language learning interests despite the participants also reporting that they learnt English through gaming. The study therefore reveals that leisure activities, such as gaming, which involve communicating with other speakers in English are key to successful and positive attitudes to language learning as a whole. 


\section{BIBLIOGRAPHY}

Abt, Clark, C. Serious Games. New York: Viking Press, 1970.

Alvarez, Julian, and Laurent Michaud. Serious Games: Advergaming, Edugaming, Training. Institut de l'audiovisuel et des télécommunications en Europe (France). Montpellier: IDATE, 2008. https:// www.researchgate.net/publication/ 286354308_Serious_Games_Advergaming_edugaming_training

Ball, Daisy. "The Writing on the... Desk: Desktop Graffiti as Unobtrusive Measure of Campus Climate Before and After the Virginia Tech Massacre." Deviant Behavior 41.3 (2019): 366-77. DOI: 10.1080/01639625.2019.1565525

Buckley, Patrick, and Elaine Doyle. “Gamification and Student Motivation." Interactive Learning Environments 24.6 (2016): 1162-75. DOI: 10.1080/10494820.2014.964263

Burwell, Catherine. "Game Changers: Making New Meanings and New Media with Video Games." English Journal 106.6 (2017): 41-47. https://library.ncte.org/journals/EJ/issues/v106-6/29180

Caillois, Roger. Man, Play, and Games. Champaign: U. of Illinois P., 2001.

Chang, Yun-Hsuan, De-Cyuan Liu, Yong-Quan Chen, and Shulan Hsieh. "The Relationship between Online Game Experience and Multitasking Ability in a Virtual Environment.” Applied Cognitive Psychology 31.6 (2017): 653-61. DOI: 10.1002/acp.3368

Chiu, Yi-hui, Chian-wen Kao, and Barry Lee Reynolds. "The Relative Effectiveness of Digital Game-Based Learning Types in English as a Foreign Language Setting: A Meta-Analysis." British Journal of Educational Technology 43.4 (2012): E104-E107. DOI: 10.1111/j.1467-8535.2012.01295.x

Deci, Edward L., Richard M. Ryan, and Richard Koestner. "The Pervasive Negative Effects of Rewards on Intrinsic Motivation: Response to Cameron (2001)." Review of Educational Research 71.1 (2001): 43-51. DOI: 10.3102/00346543071001043

Domínguez, Adrián, Joseba Saenz-de-Navarrete, Luis de-Marcos, Luis Fernández-Sanz, Carmen Pagés, and José-Javier Martínez-Herráiz. "Gamifying Learning Experiences: Practical Implications and Outcomes." Computers \& Education 63 (April 2013): 380-92. DOI: 10.1016/j.compedu.

2012.12.020

Ducheneaut, Nicolas, and Robert J Moore. "Gaining More than Experience Points: Learning Social Behavior in Multiplayer Computer Games." CHI 2004 workshop on social learning through gaming. Vienna, Austria, 2004. https://www.researchgate.net/publication/ 228645051_Gaining_more_than_experience_points_Learning_social_behavior_in_multiplayer_computer_games

Elkhafaifi, Hussein. "Listening Comprehension and Anxiety in the Arabic Language Classroom." The Modern Language Journal 89.2 (2005): 206-20. DOI: 10.1111/j.1540-4781.2005.00275.x

Ferguson, Charles A. “Diglossia.” WORD 15.2 (1959): 325-40. DOI: 10.1080/00437956.1959.11659702

Gee, James Paul. “Pleasure, Learning, Video Games, and Life: The Projective Stance." E-Learning and Digital Media 2.3 (2005): 211-23. DOI: 10.2304/elea.2005.2.3.2

Glover, Ian. "Play As You Learn: Gamification as a Technique for Motivating Learners.” Eds. J. Herrington, A. Couros \& V. Irvine. Proceedings of EdMedia 2013--World Conference on Educational Media and Technology (pp. 1999-2008). Victoria, Canada: Association for the Advancement of Computing in Education (AACE). 2013. https://www.learntechlib.org/primary/p/112246/ 
Godwin-Jones, Robert. “Language in Action: From Webquests to Virtual Realities.” Emerging Technologies 8.3 (2004): 6.

Gross, Daniel D., and Timothy D. Gross. “The Meaning of Graffiti: An Interpretation.” ETC: A Review of General Semantics 73.4 (2016): 342-47.

Henritius, Eija, Erika Löfström, and Markku S. Hannula. “University Students' Emotions in Virtual Learning: A Review of Empirical Research in the 21st Century." -BJET- British Journal of Educational Technology 50:1 (2019): 80-100. DOI: 10.1111/bjet.12699

Hsiao, Cheng-Chieh, and Jyh-Shen Chiou. "The Social Influence of Online Collaborative Community: The Moderating Effect of Achievement." Behaviour \& Information Technology 36.3 (2017): 269-80. DOI: 10.1080/0144929X.2016.1221463

Huizinga, Johan. Homo ludens. Paris: Gallimard, 1988.

Jaworski, Adam. "Metrolingual Art: Multilingualism and Heteroglossia." International Journal of Bilingualism 18.2 (2014): 134-58. DOI: 10.1177/1367006912458391

Jenkins, Jennifer. "Repositioning English and Multilingualism in English as a Lingua Franca." Englishes in Practice 2.3 (2015): 49-85. DOI: 10.1515/eip-2015-0003

Jiangnan, Qiu, Wang Chunling, and Cui Miao. "The Influence of Cognitive Conflict on the Result of Collaborative Editing in Wikipedia." Behaviour \& Information Technology 33.12 (2014): 1361-70. DOI: 10.1080/0144929X.2013.795606

Kachru, Braj B. The Alchemy of English: The Spread, Functions, and Models of Non-Native Englishes. Champaign: U. of Illinois P., 1986.

Kachru, Braj B. The Other Tongue: English Across Cultures. Champaign: U. of Illinois P., 1992.

Kohn, Kurt, and Petra Hoffstaedter. "Learner Agency and Non-Native Speaker Identity in Pedagogical Lingua Franca Conversations: Insights from Intercultural Telecollaboration in Foreign Language Education." Computer Assisted Language Learning 30.5 (2017): 351-67. DOI: 10.1080/09588221.2017.1304966

Lantolf, James P., and Steven L. Thorne. Sociocultural Theory and the Genesis of Second Language Development. Oxford: Oxford UP, 2006.

Majeski, Robin A., Merrily Stover, and Judah Ronch. "Making Asynchronous Online Learning More Learner-Oriented: An Integrated Conceptual Model with Applications for Course Design and Instruction." Educational Gerontology 42.2 (2016): 109-19. DOI: 10.1080/03601277.2015.1083389

McGonigal, Jane. Reality Is Broken: Why Games Make Us Better and How They Can Change the World. London: Penguin, 2011.

Miyake, Akira, and Naomi P. Friedman. "The Unity and Diversity of Executive Functions and Their Contributions to Complex 'Frontal Lobe' Tasks: A Latent Variable Analysis.” Cognitive Psychology 41.1 (2000): 49. DOI: 10.1006/cogp.1999.0734

Phillipson, Robert. Linguistic Imperialism. Oxford: Oxford UP, 1992.

Reardon, Robert C., and Laura K. Wright. "The Case of Mandy: Applying Holland's Theory and Cognitive Information Processing Theory." The Career Development Quarterly 47.3 (1999): 195-203. DOI: 10.1002/j.2161-0045.1999.tb00730.x

Reynolds, Alexandra. "English as a Medium of Academic Identity: Attitudes to Using English for Research and Teaching at Nantes University." PhD, University of Sussex, 2016. http:// sro.sussex.ac.uk/id/eprint/65970 
Richards, Jack C. “Drills in Language Teaching.” Professor Jack C. Richards. 27 April 2014. https:// www.professorjackrichards.com/drills-language-teaching/

Ryan, Richard M., and Edward L. Deci. "Intrinsic and Extrinsic Motivations: Classic Definitions and New Directions." Contemporary Educational Psychology 25.1 (2000): 54-67. DOI: 10.1006/ceps. 1999.1020

Sanborn, Heidi. “Developing Asynchronous Online Interprofessional Education.” Journal of Interprofessional Care 30.5 (2016): 668-70. DOI: 10.1080/13561820.2016.1182143

Smith-Robbins, Sarah. “"This Game Sucks”: How to Improve the Gamification of Education.” 7 February 2011. https://er.educause.edu/articles/2011/2/this-game-sucks-how-to-improve-thegamification-of-education

Sockett, Geoffrey. The Online Informal Learning of English. New York: Palgrave, 2014.

Tangen, Jodi L., and L. DiAnne Borders. "Applying Information Processing Theory to Supervision: An Initial Exploration.” Counselor Education and Supervision 56.2 (2017): 98-111. DOI: 10.1002/ceas. 12065

Taylor, Derrick Bryson, and Niraj Chokshi. "This Fortnite World Cup Winner Is 16 and \$3 Million Richer.” The New York Times, 29 July 2019, sec. U.S. https://www.nytimes.com/2019/07/29/us/ fortnite-world-cup-winner-bugha.html

Thorne, Steven. "The "Intercultural Turn" and Language Learning in the Crucible of New Media.' In Telecollaboration 2.0 for Language and Intercultural Learning. Bern: Peter Lang AG, 2010. 139-64.

Thorne, Steven L., Rebecca W. Black, and Julie M. Sykes. "Second Language Use, Socialization, and Learning in Internet Interest Communities and Online Gaming." The Modern Language Journal 93 (2009): 802-21. DOI: 10.1111/j.1540-4781.2009.00974.x

Tsai, Fu-Hsing, Kuang-Chao Yu, and Hsien-Sheng Hsiao. "Exploring the Factors Influencing Learning Effectiveness in Digital Gamebased Learning." Journal of Educational Technology \& Society 15.3 (2012): 240-50.

Vallerand, Robert J., Luc G. Pelletier, Marc R. Blais, Nathalie M. Briere, Caroline Senecal, and Evelyne F. Vallieres. "The Academic Motivation Scale: A Measure of Intrinsic, Extrinsic, and Amotivation in Education." Educational and Psychological Measurement 52:4 (1992): 1003-17. DOI: $10.1177 / 0013164492052004025$

Voulgari, Iro, Vassilis Komis, and Demetrios Sampson. "Learning Outcomes and Processes in Massively Multiplayer Online Games: Exploring the Perceptions of Players." Educational Technology Research \& Development 62:2 (2014): 245-70. DOI: 10.1007/s11423-013-9312-7

Wæge, Kjersti. "Intrinsic and Extrinsic Motivation Versus Social and Intrustrumental Rationale for Learning Mathematics.” ResearchGate. 2007. https://www.researchgate.net/publication/ 268415756_INTRINSIC_AND_EXTRINSIC_MOTIVATION_VERSUS_SOCIAL_AND_INSTRUMENTAL_RATIONALE_FOR_LEARNING_MATHEM

Wang, Chao-Yang, Yu-Chen Wu, Chen-Hsiang Su, Pai-Cheng Lin, Chih-Hung Ko, and Ju-Yu Yen. “Association between Internet Gaming Disorder and Generalized Anxiety Disorder." Journal of Behavioral Addictions 6:4 (2017): 564-71. DOI: 10.1556/2006.6.2017.088

Wei, Chun-Wang, Hao-Yun Kao, Hsin-Hsien Lu, and Yi Chun Liu. "The Effects of Competitive Gaming Scenarios and Personalized Assistance Strategies on English Vocabulary Learning." Journal of Educational Technology \& Society 21.3 (2018): 146-58.

Wenger, Etienne. Communities of Practice: Learning, Meaning, and Identity. Cambridge: Cambridge UP, 1999. 
Wentzel, Kathryn R., and David B. Miele. Handbook of Motivation at School. Routledge, 2016.

Young, Shelley Shwu-Ching, and Yi-Hsuan Wang. "The Game Embedded CALL System to Facilitate English Vocabulary Acquisition and Pronunciation." Journal of Educational Technology \& Society 17:3 (2014): 239-51.

Zichermann, Gabe, and Christopher Cunningham. Gamification by Design: Implementing Game Mechanics in Web and Mobile Apps. O'Reilly Media, Inc., 2011.

\section{APPENDIXES}

\section{A survey about gaming}

- How many hours on average do you (or did you) spend playing games a week?

- What games do you play in which you communicate (orally or through written texts) with other players in English?

-Which countries do the other gamers come from?

- How do you communicate with other players, by written or oral communication?

- Oral, written, other:

- Gaming has helped me to improve my overall English skills:

- Strongly agree, somewhat agree, neither agree nor disagree, somewhat disagree, strongly disagree

- Can you give some examples of any words that you have learnt through gaming?

- How old are you?

- What gender are you?

-Would you be available for an interview?

- If yes, please write your email address in the box below

\section{Gaming in English: Interview schedule}

-Why do you play video games?

-What games do you play?

-What type of games are they?

- Does gaming help your English?

-If yes, how does it help your English?

- When do you use English?

- Game play

- Oral Communication

- Forums

- Walkthroughs

- Does being good at English help during the game?

- Can you apply the English learnt to any other areas?

- How should games/gaming be used at the university?

- Should the university favour educational or non-educational games?

-Would you be in favour of a gaming room with consoles at the language centre?

-What do you think of the translations of the games?

List of words cited by the respondents, listed alphabetically 


\begin{tabular}{|c|c|c|c|c|}
\hline ability & Act & add & $\begin{array}{l}\text { AFK (AWAY FROM } \\
\text { KEYBOARD) }\end{array}$ & aim \\
\hline ammo & ammunition & anvil & appeal & arguments \\
\hline armor & armory & arms & arrows & $\begin{array}{l}\text { asap (AS SOON AS } \\
\text { POSSIBLE) }\end{array}$ \\
\hline assault & assault rifle & attack & attack speed & axe \\
\hline backdoor & badmouthing & bait & ban & bank \\
\hline barracks & basement & battleground & beverage & bind \\
\hline blaze & boosting & bot & bow & $\begin{array}{l}\text { brb (BE RIGHT } \\
\text { BACK) }\end{array}$ \\
\hline break & brethren & buckler & buff & bullet \\
\hline burgler & burst & by the way & call & careful \\
\hline carry & cast & castle & chainmail & character \\
\hline chase & chest & chestplate & choke & cleaver \\
\hline coal & cobblestone & cobweb & coin & collapse \\
\hline complaint & copper & corner & countdown & crab \\
\hline craft & creepy & crew & crossbow & crouch \\
\hline crow & crowd & curse & damage & dash \\
\hline deaf & defuse & delighted & dirt & disban \\
\hline diving & $\begin{array}{l}\text { do you follow } \\
\text { my lead? }\end{array}$ & dodge & drink & drop \\
\hline dropper & dropshot & drought & duck & dummy \\
\hline dwarf & earl & early bird & emerald & endeavour \\
\hline engine & exhaust & exhibition game & expenditure & facecheck \\
\hline faceroll & farming & fast & feed & fence \\
\hline fists & flag & flank & focus & follow \\
\hline food & foolish & forfait & forklift & fortress \\
\hline frame & free kick & freeze & gambling & gate \\
\hline gauntlet & gears & gg (GOOD GAME) & giggling & $\begin{array}{l}\text { glhf (GOOD LUCK } \\
\text { HAVE FUN) }\end{array}$ \\
\hline
\end{tabular}




\begin{tabular}{|c|c|c|c|c|}
\hline glove & goalkeeper & goat & gold & goods \\
\hline granary & grasp & grass & gravel & greaves \\
\hline greed & grenade & grind & gtg (GOT TO GO) & gun \\
\hline hard & hardened clay & head shot & heal & health \\
\hline health points & heap & heist & hell & hello guys \\
\hline helmet & high grounds & high noon & hill & hit \\
\hline ignite & I'm heading west & incomes & incoming & innards \\
\hline innate & invade & iron & iron ore & item \\
\hline jammin' & jar & jetpack & jump & keyboard \\
\hline kit & kite & knee & knife & lad \\
\hline lag & lap & laser beam & lava & leash \\
\hline leaves & left/right wing & let's rush & library & lifesteal \\
\hline lmao & locket & loop & loot & lurk \\
\hline $\begin{array}{l}\text { make your } \\
\text { acquaintance }\end{array}$ & marksman & mate & merit & middle \\
\hline mine & minecart & minion & monk & moor \\
\hline movement speed & murderer & mute & $\begin{array}{lll}\text { ngl } & \text { (NOT GONNA } \\
\text { LIE) } & & \end{array}$ & noob \\
\hline obsidian & ofc (OF COURSE) & orb & overextending & pain \\
\hline pal & pause & peacock & peek & peel \\
\hline pick & pickaxe & pike & ping & play \\
\hline player & props & race & racoon & redstone \\
\hline remain & report & reset & retarded & roam \\
\hline rush & save & scale & scavenge & seagull \\
\hline secret & selector & sheep & shield & shift \\
\hline ship & shoulders & shovel & skill & skill shot \\
\hline skull & slide & slow & $\begin{array}{l}\text { smh (SHAKING MY } \\
\text { HEAD) }\end{array}$ & smite \\
\hline sneak & snowballing & sound & spawn & spear \\
\hline
\end{tabular}




\begin{tabular}{|c|c|c|c|c|}
\hline spell & spires & squirrel & squishy & stack \\
\hline stairs & stamina & start & stealth & steel \\
\hline stockpile & stone & strength & stride & striker \\
\hline stuff & stun & stunt & summon & supplies \\
\hline support & surrender & swap & tbh (TO BE HONEST) & tears \\
\hline teleport & thanks m8 & the front & theft & $\begin{array}{l}\text { there's a sniper } \\
\text { on that hill }\end{array}$ \\
\hline thief & thirst & tho (THOUGH) & thou art & though \\
\hline thwart & thy & tilt & tires & to be honest \\
\hline toe & token & tool & top & tournament \\
\hline trade & trap & treachery & tree & trickster \\
\hline trigger & trinquets & $\begin{array}{l}\text { TTLY (TALK TO } \\
\text { YOU LATER) }\end{array}$ & $\mathrm{u}(\mathrm{YOU})$ & units \\
\hline use & vanish & wages & ward & warrior \\
\hline weapon & weld & well & what's up & wheels \\
\hline will & wisp & wizard & wood & you suck \\
\hline
\end{tabular}

\section{NOTES}

1. Online gaming is a term used to refer to video gaming which uses the internet.

2. Drilling is an example of mechanical practice (Richards 2014) consisting in making pupils or students orally repeat target vocabulary or structures.

3. Online informal learning of English is defined as incidental language learning that takes place online (Sockett 2014).

4. Serious games are defined as games that "have an explicit and carefully thought-out educational purpose and are not intended to be played primarily for amusement" (Abt 1970: 9).

5. The term 'gaming' will be used to refer to the activity of players who are involved in 'video gaming'.

6. Motivation is a theoretical framework for understanding learner behaviour and orientation (Ryan \& Deci 2000).

7. See Buckley and Doyle (2016) for an overview of motivation in relation to gamification, as well as Vallerand et al. (1992).

8. The questionnaire was sent out to 200 undergraduates who study at Collège Sciences et Technologies, University of Bordeaux, where the authors also work. 90 participants responded to the survey. Eight of these participants were subsequently interviewed. Participants could signal whether they wished to be interviewed in the questionnaire.

9. Their specialities were either Geology, Computer Science, Maths, Chemistry, or Physics. 
10. According to l'Essentiel du Jeu Vidéo (October 2019), men represent $52 \%$ of gamers in France. The present study shows a higher percentage of male gamers, but this is perhaps in keeping with the proportion of male to female students at the School of Science of the University of Bordeaux which made up the participants of this study.

11. The use of English in French Higher Education, and increasingly in wider society, is classified as a second language and not as a foreign language (Reynolds 2016; Kachru 1992). French schoolchildren usually learn two second languages: English and Spanish, or English and German, for example, in keeping with the multilingual language policy of the European Commission.

12. All translations provided by the authors.

13. This CEFR level was gleaned by the authors (trained language proficiency assessors) during interviews.

\section{ABSTRACTS}

Gaming, where users put into application their language repertoire in an informal context, involves language. For speakers of English as a Second Language (L2), gaming provides access to the wider English-speaking community of English as lingua franca speakers (Jenkins 2015; Kachru 1986). According to Thorne et al. online games "comprise the most socially and cognitively complex forms of interactive media currently available" (2009: 808). To this end, gamers use language through a variety of modes, including speaking and writing. In addition, the skills and capacities needed to instant-message whilst gaming are forming new types of literacy and communication (Godwin-Jones 2004). In accordance with online language learning theories which argue that language learning occurs "in the wild" (Thorne 2010: 144), online interaction can give L2 speakers access to "real talk" rather than the simulated or role-played talk of the second language classroom (Kohn \& Hoffstaedter 2017). Motivation for learning a language for gaming can therefore be aligned to intrinsic motivational language learning models (Ryan \& Deci 2000; Wæge 2007). The present study considers French youths who use online games in English and asks what makes the language and environment of gaming an accessible way to learn English. The methods used were an online survey and interviews of students at the University of Bordeaux who reported on how gaming helped them to improve their English through immersion. The results show that the online nature of the exchanges between the speakers made the speakers feel more confident when trying to communicate in English (both within the game and when interacting with others in English when not gaming). In addition, the repetitive nature of games and gaming vocabulary helped the participants to learn English words and phrases without the impression of being drilled. The immersive experience facilitated by games gave L2 speakers of English the ability to travel virtually outside of their L1 local language environment.

Les jeux où les usagers appliquent effectivement leur répertoire de langage dans un contexte informel impliquent l'usage du langage. Pour ceux dont l'anglais est la deuxième langue, les jeux en ligne fournissent un accès à la communauté élargie des utilisateurs de la langue anglaise comme lingua Franca (Jenkins 2015; Kachru 1986). Selon Thorne et al., les jeux en ligne «regroupent les formes de médias interactifs les plus sociales et complexes disponibles actuellement en matière cognitive " (2009: 808). A cette fin, les joueurs utilisent le langage à travers une variété de fonctions, qui incluent la parole et l'écriture. Par ailleurs, les compétences et capacités nécessaires pour échanger des messages instantanés pendant les jeux en ligne 
forment de nouvelles formes de littérature et communication (Godwin-Jones 2004). Conformément aux théories de l'apprentissage des langues en ligne, qui soutient que l'apprentissage des langues a lieu dans «dans un contexte naturel» (Thorne 2010: 144), l'interaction en ligne peut donner aux utilisateurs de l'anglais comme deuxième langue un accès à un « langage réel » plutôt qu'à un langage simulé ou relevant des discussions liées à des jeux de rôles survenant dans les cours de langues (Kohn \& Hoffstaedter 2017). La motivation pour apprendre une langue à des fins de jeux en ligne peut donc s'aligner sur celle de la motivation intrinsèque aux modèles existants concernant l'apprentissage des langues (Ryan \& Deci 2000; Wæge 2007). Cette étude s'intéresse à des jeunes français utilisant des jeux en ligne en anglais pour se demander dans quelle mesure le langage et l'environnent des jeux en ligne constituent un moyen accessible d'apprendre l'anglais. Nous nous appuyons sur un sondage en ligne et plusieurs entretiens réalisés auprès d'étudiants de l'Université de Bordeaux qui avaient affirmé avoir amélioré leur anglais à travers l'immersion dans les jeux en ligne. Les résultats montrent que la nature virtuelle des échanges entre les participants a rendu les communicants plus confiants dans leur manière de s'exprimer en anglais (que ce soit dans le contexte des jeux en ligne ou en dehors). De plus, la nature répétitive et le vocabulaire des jeux semblent avoir aidé les participants à apprendre de nouveaux mots et phrases en anglais sans avoir l'impression d'avoir été forcés à les apprendre par cœur. L'aspect immersif des jeux a ainsi donné à ceux dont l'anglais est la deuxième langue la capacité de voyager «virtuellement» hors de leur environnement linguistique familier.

\section{INDEX}

Mots-clés: jeux en ligne, environnement d'apprentissage virtuel, motivation, apprentissage de l'anglais, jeux vidéo, jeux

Keywords: online gaming, virtual learning environment, motivation, English language learning, video games, games

\section{AUTHORS}

\section{JENI PEAKE}

Jeni Peake is a PhD candidate and English language teacher at the University of Bordeaux, France. She obtained a Master's degree in Anglophone Studies in 2019 from the University of Bordeaux Montaigne. Her main areas of study are language hybridity in public spaces, with a particular focus on graffiti. Her thesis title is "Urban graffiti and inscriptions as linguistic markers of language flux and hybridity in France: implications for English language teaching." Contact: Jeni.peake [at] u-bordeaux.fr

\section{ALEXANDRA REYNOLDS}

Dr. Alexandra Reynolds is an Associate Professor of English and Linguistics at the University of Bordeaux, France. Dr. Reynolds' main research areas are English as a medium of professional identity, virtual exchange and language identity. Contact: alexandra.reynolds [at] u-bordeaux.fr 